Yol.2 2Nn. I لanuari 2019

ISSN 2614-2775

e-ISSN 2621-8143

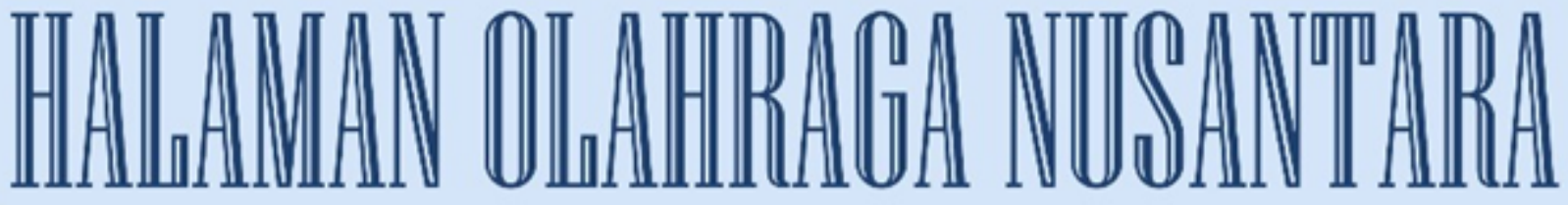

Surnal @lmu Xeolahragaan

Diterbitkan Oleh:

Program Studi Pendidikan Olahraga

Fakultas Keguruan dan Ilmu Pendidikan

Universitas PGRI Palembang

Jurnal

Volume Nomor Halaman Palembang ISSN/e-ISSN

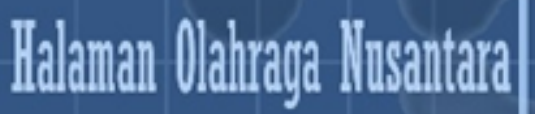

\begin{tabular}{l|l|l|l}
2 & 1 & $1-96$ & 2019
\end{tabular}




\section{Halaman Olahraga Nusantara}

Jurnal Ilmu Keolahragaan

Volume 2, Nomor 1, Januari 2019

Pelindung/Penasehat

Dr. H. Bukman Lian, M. M., M. Si.

Penanggung Jawab

Dr. Dessy Wardiah, M. Pd.

Ketua Dewan Redaksi

Farizal Imansyah, M. Pd.

Wakil Ketua Dewan Redaksi

Ilham Arvan Junaidi, M. Pd.

Sekretaris

Bayu Iswana, M. Pd.

Penyunting Pelaksana

Rafel Orlando, M. Pd.

Ardo Okilanda, M. Pd.

Daryono, M. Pd.

\section{Mitra Bestari}

Prof. Dr. A. Sofyan Hanif, M. Pd (Universitas Negeri Jakarta)

Dr. Sukirno (Universitas Sriwijaya)

Dr. Ronni Yenes, M. Pd (Universitas Negeri Padang)

Dr. Benny, M. Pd. (Universitas Negeri Makasar)

Dr. Putri Cicilia Kristina, M. Pd (Universitas PGRI Palembang)

\section{Tata Usaha}

M. Taheri Akbar, M. Pd.

Widya Handayani, S. Pd., M. Si.

Setting:

Dede Dwiansyah Putra, M. Pd.

Alamat Redaksi:

Prodi Pendidkan Olahraga Fakultas Keguruan Ilmu dan Pendidikan Universitas PGRI Palembang

Jl. Jendral A. Yani Lorong Gotong Royong 9/10 Ulu Palembang

Telp. 0711-510043, Fax. 0711-514782

e-mail jurnal: jurnalhonupgripalembang@gmail.com

e-mail : ardo.oku@univpgri-palembang.ac.id

website: univpgri-palembang.ac.id 
Halaman Olahraga Nusantara (Jurnal Ilmu Keolahragaan)

P-ISSN 2614-2775

Volume 2, No. 1, Januari 2019

E-ISSN 2621-8143

\section{DAFTAR ISI}

Hasil Penelitian

Halaman

Pengaruh Metode Rangkaian Bermain Terhadap Keterampilan Dasar Olahraga Panahan Siswa Ektrakulikuler Sit (Sekolah Islam Terpadu) Auladi Palembang

- Arisman

Penerapan Metode Bermain Dalam Meningkatkan Hasil Belajar Guling Depan (Forward Roll)

- Ruslan, M. Samsul Huda

Survei Tingkat Kesegaran Jasmani pada Peserta Ekstrakulikuler Sepakbola Di Sma Negeri 2 Oku

- Daryono

Kontribusi Daya Ledak Tungkai dan Keseimbangan Terhadap Kemampuan Lompat Jauh Murid Sd Negeri 139 Sinjai

- Adam Mappaompo

Survei Tingkat Kebugaran Jasmani Mahasiswa Pendidikan Olahraga Angkatan 2017 Stkip Pgri Bangkalan

- Heni Yuli Handayani .

Profil Delayed Onset Muscle Soreness (Doms) pada Mahasiswa Fik Unp Setelah Latihan Fisik

- Heru Syarli Lesmana

Perbedaan Pengaruh Latihan Menggunakan Karet dengan Menggunakan Dumbbell $1 \mathrm{Kg}$ Terhadap Kecepatan Pukulan Oi Tsuki

Chudan pada Atlet Karate Putra Perguruan Wadokai Dojo Sma Negeri 11 Medan Tahun 2017

- Pangondian Hotliber Purba $60-71$

Tinjauan Kondisi Fisik Atlet Sepakbola Kabupaten Kerinci Dalam

Rangka Persiapan Mengikuti Porprov Xxii Bungo Tebo 2018

- Palmizal, Wawan Junresti Daya, dan Sri Murniati

Aktivitas Jasmani dan Persepsi Gerak Anak Usia Dini

- Dian Pujianto 
Peningkatan Keterampilan Bermain Bolabasket Mahasiswa Melalui Latihan Aktifitas Maze Perkuliahan Permainan Bolabasket

- Ilham Arvan Junaidi dan Rury Rizhardy $88-96$ 


\title{
SURVEI TINGKAT KEBUGARAN JASMANI MAHASISWA PENDIDIKAN OLAHRAGA ANGKATAN 2017 STKIP PGRI BANGKALAN
}

\author{
Oleh: Heni Yuli Handayani \\ (Dosen STKIP PGRI Bangkalan)
}

\begin{abstract}
Abstrak
Olahraga sangat berkaitan dengan prestasi, prestasi olah raga yang diperoleh tidak lepas dari beberapa faktor yang salah satu diantaranya adalah kesegaran jasmani. Berkaitan dengan hal tersebut kesegaran jasmani yang dimiliki oleh mahasiswa olahraga angkatan 2017 STKIP PGRI Bangkalan belum diketahui. Adapun tujuan penelitian ini adalah untuk mengetahui Tingkat Kesegaran Jasmani mahasiswa pendidikan olahraga di STKIP PGRI Bangkalan. Penelitian ini merupakan penelitian deskriptif menggunakan metode survei. Subyek penelitian ini adalah Mahasiswa pendidikan olahraga angkatan 2017 di STKIP PGRI Bangkalan 39 mahasiswa. Teknik pengambilan data menggunakan instrumen TKJI tahun 2010 yang terdiridari 5 item tes yaitu: Tes lari 50 meter, gantung angkat tubuh 60 detik, baring duduk 60 detik, loncat tegak, lari 1000 meter. Teknik analisis data yang digunakan dalam penelitian ini adalah analisis statistic deskriptif dengan persentase. Hasil penelitian menunjukkan bahwa Tingkat Kesegaran Jasmani Mahasiswa yaitu sebanyak 25 mahasiswa mempunyai kondisi fisik kurang, 14 mahasiswa mempunyai kondisi fisik sedang. Frekuensi terbanyak pada kategori kurang, yaitu sebanyak 25 mahasiswa, sehingga dapat disimpulkan bahwa Tingkat Kesegaran Jasmani Mahasiswa Pendidikan olahragaangkatan 2017 adalah sebagian besar masuk kategori kurang.
\end{abstract}

Kata Kunci: Kesegaran Jasmani, Kondisi Fisik, Mahasiswa Pendidikan Olahraga

\section{A PHYSICAL FITNESS LEVEL SURVEY AT 2017 SPORTS EDUCATION STUDENTS STKIP PGRI BANGKALAN}

\begin{abstract}
Exercise is closely related to achievement, sports achievements obtained cannot be separated from several factors, one of which is physical fitness. In connection with this matter the physical freshness possessed by sports students of the 2017 STKIP PGRI Bangkalan class is unknown. The purpose of this study was to determine the level of physical fitness of sports education students at STKIP Bangkri PGRI. This research is a descriptive study using survey methods. The subjects of this study were 2017 students of sports education at STKIP PGRI Bangkalan, 39 students. The data collection technique used the TKJI instrument in 2010 which consisted of 5 test items, namely: 50 meter running test, body lift hanging 60 seconds, lying sitting 60 seconds, jumping upright, running 1000
\end{abstract}


meters. The data analysis technique used in this study is descriptive statistical analysis with percentages. The results showed that the level of physical fitness of the students as many as 25 students had less physical conditions, 14 students had moderate physical conditions. The most frequency in the category is less, that is as many as 25 students, so it can be concluded that the level of Physical Education Students' Physical Freshness in 2017 is mostly in the less category.

Keywords: Physical Fitness, Physical Condition, Physical Education Student

\section{A. PENDAHULUAN}

Kegiatan olahraga merupakan kegiatan yang tiada putus-putusnya, bahkan dapat dikatakan bahwa olahraga sudah merupakan suatu bagian dari kegiatan hidup manusia olahraga sudah merupakan kebutuhan hidup manusia. Dengan berolahraga terutama olahraga kesehatan akan dapat memelihara dan meningkatkan derajat hidup manusia. Tanpa olahraga akan terjadi penurunan kesehatan dan memperbesar kemungkinan terserang penyakit non infeksi. Kebugaran jasmani yang tinggi diperlukan oleh semua orang. Dengan memiliki kebugaran jasmani yang tinggi, individu mampu melakukan aktivitas sehari-hari dengan waktu yang lebih lama dibandingkan dengan siswa yang memiliki kebugaran jasmani yang rendah. Seperti pada literatur oleh Karhiwikarta, (1991) : "Kebugaran jasmani pada hakikatnya merupakan suatu kondisi tubuh yang mencerminkan kemampuan seseorang untuk melakukan pekerjaan sehari-hari tanpa mengalami kelelahan yang berlebihan dan masih mempunyai cadangan tenaga untuk menikmati waktu senggangnya dengan baik maupun melakukan pekerjaan yang tidak terduga".

Kebugaran jasmani mempunyai arti penting bagi anak usia sekolah, antara lain dapat meningkatkan fungsi organ tubuh, sosial emosional, sportivitas, dan semangat kompetisi. Bahkan beberapa penelitian menyebutkan bahwa: kebugaran jasmani mempunyai hubungan positif dengan prestasi akademis (Adisapoetra, dkk, 1999). Selain itu, tingkat kebugaran jasmani bukan hanya untuk memelihara tubuh yang sehat, melainkan juga untuk menyembuhkan tubuh yang tidak sehat (Cooper, 1983). 


\section{B. METODE PENELITIAN}

Penelitian yang akan digunakan dalam penelitian ini adalah penelitian eksperimen. Menurut Sugiyono (2012:72) penelitian eksperimen diartikan sebagai metode penelitian yang digunakan untuk mencari pengaruh perlakuan tertentu terhadap yang lain dalam kondisi yang terkendalikan. Penelitian ini merupakan penelitian kuantitatif, yang mana penelitian ini di arahkan dalam bentuk mencari data-data kuantitatif. Data yang digunakan untuk menganalisis pendekatan kuantitatif ini adalah data berupa angka. Jenis penelitian eksperimen yang akan digunakan peneliti adalah Pre-Experimental Designs dengan OneGroup Pretest-Posttest Design. Peneliti menggunakan Pre-Experimental Designs karena tidak adanya variabel kontrol, dan sampel tidak dipilih secara random. Desain ini terdapat pretest (tes denyut nadi \& tekanan darah) sebelum perlakuan dan terdapat post test (tes denyut nadi \& tekanan darah) setelah perlakuan. Perlakuannya berupa Tes TKJI (Tes Kebugaran Jasmani Indonesia). Dengan demikian hasil perlakuan dapat diketahui lebih akurat, karena dapat membandingkan dengan keadaan sebelum diberi perlakuan (Sugiyono, 2012:74).

Sampel adalah bagian dari jumlah dan karakteristik yang dimiliki oleh populasi tersebut (Sugiyono,2011:120). Teknik sampling yang di gunakan dalam penelitian ini nonprobality sampling. Teknik pengambilan sampel dalam penelitian ini dilakukan dengan sampling jenuh, dimana semua anggota populasi digunakan sebagai sampel. Dengan demikian, sampel yang diambil dalam penelitian ini adalah seluruh anggota dari populasi mahasiswa baru pendidikan olahraga yaitu anggota populasi yang berjumlah 39 siswa. Populasi adalah wilayah generalisasi yang terdiri atas: objek yang mempunyai kualitas dan karakteristik tertentu yang di tetapkan oleh peneliti untuk di pelajari dan kemudian di tarik kesimpulanya (sugiyono,2011:119). Teknik pengumpulan data yang digunakan dalam penelitian ini adalah teknik survey. Metode survei adalah penyelidikan yang diadakan untuk memperoleh fakta-fakta dari gejala-gejala yang ada dan mencari kekurangan-kekurangan secara faktual (Suharsimi Arikunto, 2006:56). Dengan menggunakan tes pengukuran yaitu peneliti mengamati secara langsung pelaksanaan tes TKIJ (Tes Kebugaran Jasmani Indonesia) dan 
pengukuran dilapangan. Tes dan pengukuran digunakan untuk mengetahui tingkat kebugaran jasmani mahasiswa baru pendidikan olahraga.

\section{HASIL PENELITIAN}

Penelitian Kebugaran Mahasiswa Putra kelas 5F, dapat di deskripsikan bahwa pada saat melakukan pengujian denyut nadi sebelum dan sesudah melakukan kebugaran jasmani tes denyut nadi tiap mahasiswa berbeda- beda. Dan hasil dari tes Push Up, Shit Up, Loncat, dan Lari Spirit juga dilakukan. Seperti yang dilihat di tabel A. R sebelum melakukan kebugaran jasmani denyut nadi terhitung 84 dan tekanan darah 110/70, tetapi setelah melakukan tes kebugaran jasmani denyut nadi meningkat menjadi 168 dan tekanan darahnya menurun menjadi 110/60; Push Up dengan total 23 kali, Sit Up sebanyak 36 kali, loncat setinggi $258 \mathrm{~cm}$ dan lari Sprint dengan waktu 11,3; sehingga jumlah nilai kebugaran jasmani yang diperoleh sebanyak 13 dan klasifikasi tingkat kesegaran jasmaninya kurang. A S. sebelum melakukan kebugaran jasmani denyut nadi terhitung 100 dan tekanan darah 120/80, tetapi setelah melakukan tes kebugaran jasmani denyut nadi meningkat menjadi 190 dan tekanan darahnya menurun menjadi 120/70; Push Up dengan total 26 kali, Sit Up sebanyak 34 kali, loncat setinggi $271 \mathrm{~cm}$ dan lari Sprint dengan waktu 9,3; sehingga jumlah nilai kebugaran jasmani yang diperoleh sebanyak 15 dan klasifikasi tingkat kesegaran jasmaninya sedang. M. S sebelum melakukan kebugaran jasmani denyut nadi terhitung 80 dan tekanan darah 120/80, tetapi setelah melakukan tes kebugaran jasmani denyut nadi dan tekanan darahnya meningkat menjadi 164 dan 140/70; Push Up dengan total 21 kali, Sit Up sebanyak 34 kali, loncat setinggi $282 \mathrm{~cm}$ dan lari Sprint dengan waktu 10,4; sehingga jumlah nilai kebugaran jasmani yang diperoleh sebanyak 14 dan klasifikasi tingkat kesegaran jasmaninya sedang sebelum melakukan kebugaran jasmani denyut nadi terhitung 90 dan tekanan darah 110/70, tetapi setelah melakukan tes kebugaran jasmani denyut nadi dan tekanan darahnya meningkat menjadi 230 menurun menjadi 140/60; Push Up dengan total $25 \mathrm{kali}$, Sit Up sebanyak $36 \mathrm{kali}$, loncat setinggi $210 \mathrm{~cm}$ dan lari 
Sprint dengan waktu 9,5; sehingga jumlah nilai kebugaran jasmani yang diperoleh sebanyak 15 dan klasifikasi tingkat kesegaran jasmaninya sedang.

DK sebelum melakukan kebugaran jasmani denyut nadi terhitung 84 dan tekanan darah 120/90, tetapi setelah melakukan tes kebugaran jasmani denyut nadi dan tekanan darahnya meningkat menjadi 160 dan 130/60; Push Up dengan total 5 kali, Sit Up sebanyak 26 kali, loncat setinggi $270 \mathrm{~cm}$ dan lari Sprint dengan waktu 9,8; sehingga jumlah nilai kebugaran jasmani yang diperoleh sebanyak 11 dan klasifikasi tingkat kesegaran jasmaninya kurang. Martenus sebelum melakukan kebugaran jasmani denyut nadi terhitung 80 dan tekanan darah 90/60, tetapi setelah melakukan tes kebugaran jasmani denyut nadi menurun menjadi 74 dan tekanan darahnya meningkat menjadi 130/70; Push Up dengan total 33 kali, Sit $U p$ sebanyak $26 \mathrm{kali}$, loncat setinggi $250 \mathrm{~cm}$ dan lari sprint dengan waktu 9,9; sehingga jumlah nilai kebugaran jasmani yang diperoleh sebanyak 14 dan klasifikasi tingkat kesegaran jasmaninya sedang. B S. sebelum melakukan kebugaran jasmani denyut nadi terhitung 80 dan tekanan darah 120/70, tetapi setelah melakukan tes kebugaran jasmani denyut nadi meningkat dan tekanan darahnya menjadi 84dan 140/60; Push Up dengan total 20 kali, Sit Up sebanyak 30 kali, loncat setinggi $270 \mathrm{~cm}$ dan lari Sprint dengan waktu 9; sehingga jumlah nilai kebugaran jasmani yang diperoleh sebanyak 13 dan klasifikasi tingkat kesegaran jasmaninya kurang. Primanda sebelum melakukan kebugaran jasmani denyut nadi terhitung 84 dan tekanan darah 120/70, tetapi setelah melakukan tes kebugaran jasmani denyut nadi meningkat dan tekanan darahnya menjadi 136 dan 140/80; Push Up dengan total 16 kali, Sit Up sebanyak 20 kali, loncat setinggi 220 cm dan lari Sprint dengan waktu 9,7; sehingga jumlah nilai kebugaran jasmani yang diperoleh sebanyak 13 dan klasifikasi tingkat kesegaran jasmaninya kurang. FR sebelum melakukan kebugaran jasmani denyut nadi terhitung 70 dan tekanan darah 120/90, tetapi setelah melakukan tes kebugaran jasmani denyut nadi meningkat dan tekanan darahnya menjadi 160 dan 130/70; Push Up dengan total $18 \mathrm{kali}$, Sit Up sebanyak $26 \mathrm{kali}$, loncat setinggi $250 \mathrm{~cm}$ dan lari Sprint dengan waktu 9,2; sehingga jumlah nilai kebugaran jasmani yang diperoleh sebanyak 13 dan klasifikasi tingkat kesegaran jasmaninya kurang. I A sebelum melakukan 
kebugaran jasmani denyut nadi terhitung 80 dan tekanan darah 120/80, tetapi setelah melakukan tes kebugaran jasmani denyut nadi meningkat dan tekanan darahnya menjadi 144 dan 140/60; Push Up dengan total 31 kali, Sit Up sebanyak 31 kali, loncat setinggi $270 \mathrm{~cm}$ dan lari Sprint dengan waktu 10,2; sehingga jumlah nilai kebugaran jasmani yang diperoleh sebanyak 15 dan klasifikasi tingkat kesegaran jasmaninya sedang. $\mathrm{Tq}$ sebelum melakukan kebugaran jasmani denyut nadi terhitung 80 dan tekanan darah 110/70, tetapi setelah melakukan tes kebugaran jasmani denyut nadi meningkat dan tekanan darahnya menjadi 178 dan 100/70; Push Up dengan total 27 kali, Sit Up sebanyak 32 kali, loncat setinggi 256 cm dan lari Sprint dengan waktu 11,7; sehingga jumlah nilai kebugaran jasmani yang diperoleh sebanyak 13 dan klasifikasi tingkat kesegaran jasmaninya kurang. DC sebelum melakukan kebugaran jasmani denyut nadi terhitung 115 dan tekanan darah 120/80, tetapi setelah melakukan tes kebugaran jasmani denyut nadi meningkat dan tekanan darahnya menjadi 280 dan 140/70; Push Up dengan total 32 kali, Sit Up sebanyak $38 \mathrm{kali}$, loncat setinggi $285 \mathrm{~cm}$ dan lari Sprint dengan waktu 9,2; sehingga jumlah nilai kebugaran jasmani yang diperoleh sebanyak 16 dan klasifikasi tingkat kesegaran jasmaninya sedang. M I sebelum melakukan kebugaran jasmani denyut nadi terhitung 148 dan tekanan darah 120/70, tetapi setelah melakukan tes kebugaran jasmani denyut nadi meningkat dan tekanan darahnya menjadi 172 dan 150/10; Push Up dengan total 30 kali, Sit Up sebanyak 15 kali, loncat setinggi $240 \mathrm{~cm}$ dan lari Sprint dengan waktu 10,6; sehingga jumlah nilai kebugaran jasmani yang diperoleh sebanyak 13 dan klasifikasi tingkat kesegaran jasmaninya kurang. EN sebelum melakukan kebugaran jasmani denyut nadi terhitung 120 dan tekanan darah 120/70, tetapi setelah melakukan tes kebugaran jasmani denyut nadi meningkat dan tekanan darahnya menjadi 210 dan 130/60; Push Up dengan total 18 kali, Sit Up sebanyak 26 kali, loncat setinggi 268 cm dan lari Sprint dengan waktu 10,1; sehingga jumlah nilai kebugaran jasmani yang diperoleh sebanyak 12 dan klasifikasi tingkat kesegaran jasmaninya kurang. SM sebelum melakukan kebugaran jasmani denyut nadi terhitung 80 dan tekanan darah 120/80, tetapi setelah melakukan tes kebugaran jasmani denyut nadi meningkat dan tekanan darahnya menjadi 154 dan 110/70; Push Up dengan total 
26 kali, Sit Up sebanyak 36 kali, loncat setinggi $270 \mathrm{~cm}$ dan lari Sprint dengan waktu 9,1; sehingga jumlah nilai kebugaran jasmani yang diperoleh sebanyak 15 dan klasifikasi tingkat kesegaran jasmaninya sedang. Af sebelum melakukan kebugaran jasmani denyut nadi terhitung 80 dan tekanan darah 120/70, tetapi setelah melakukan tes kebugaran jasmani denyut nadi meningkat dan tekanan darahnya menjadi 184 dan 110/70; Push Up dengan total 23 kali, Sit Up sebanyak 31 kali, loncat setinggi $268 \mathrm{~cm}$ dan lari Sprint dengan waktu 10,2; sehingga jumlah nilai kebugaran jasmani yang diperoleh sebanyak 14 dan klasifikasi tingkat kesegaran jasmaninya sedang.

RM. sebelum melakukan kebugaran jasmani denyut nadi terhitung 72 dan tekanan darah 110/70, tetapi setelah melakukan tes kebugaran jasmani denyut nadi dan tekanan darahnya meningkat menjadi 104 dan 140/100. Neni T. sebelum melakukan kebugaran jasmani denyut nadi terhitung 92 dan tekanan darah 120/60, tetapi setelah melakukan tes kebugaran jasmani denyut nadi dan tekanan darahnya meningkat menjadi 159 dan 140/80. R H. M. sebelum melakukan kebugaran jasmani denyut nadi terhitung 100 dan tekanan darah 110/70, tetapi setelah melakukan tes kebugaran jasmani denyut nadi dan tekanan darahnya meningkat menjadi 184 dan 140/60. Niswatul F sebelum melakukan kebugaran jasmani denyut nadi terhitung 60 dan tekanan darah 110/70, tetapi setelah melakukan tes kebugaran jasmani denyut nadi dan tekanan darahnya meningkat menjadi 120 dan 130/70. Ch sebelum melakukan kebugaran jasmani denyut nadi terhitung 80 dan tekanan darah 120/60, tetapi setelah melakukan tes kebugaran jasmani denyut nadi dan tekanan darahnya meningkat menjadi 160 dan 120/70. Wam sebelum melakukan kebugaran jasmani denyut nadi terhitung 80 dan tekanan darah 120/60, tetapi setelah melakukan tes kebugaran jasmani denyut nadi dan tekanan darahnya meningkat menjadi 152 dan 140/60. Mus sebelum melakukan kebugaran jasmani denyut nadi terhitung 78 dan tekanan darah 110/70, tetapi setelah melakukan tes kebugaran jasmani denyut nadi meningkat menjadi 142 dan tekanan darahnya tetap. Imaniar sebelum melakukan kebugaran jasmani denyut nadi terhitung 76 dan tekanan darah 110/70, tetapi setelah melakukan tes kebugaran jasmani denyut nadi meningkat menjadi 156 dan tekanan darahnya menurun menjadi 100/60. 
Khai N. sebelum melakukan kebugaran jasmani denyut nadi terhitung 124 dan tekanan darah 110/90, tetapi setelah melakukan tes kebugaran jasmani denyut nadi meningkat menjadi 210 dan tekanan darahnya menurun menjadi 110/70.Ism sebelum melakukan kebugaran jasmani denyut nadi terhitung 112 dan tekanan darah 110/70, tetapi setelah melakukan tes kebugaran jasmani denyut nadi dan tekanan darahnya meningkat menjadi 162 dan 110/60.Roi sebelum melakukan kebugaran jasmani denyut nadi terhitung 92 dan tekanan darah 120/70, tetapi setelah melakukan tes kebugaran jasmani denyut nadi dan tekanan darahnya meningkat menjadi 154 dan 120/60.Kamelia sebelum melakukan kebugaran jasmani denyut nadi terhitung 76 dan tekanan darah 110/70, tetapi setelah melakukan tes kebugaran jasmani denyut nadi dan tekanan darahnya meningkat menjadi 152 dan 100/60.Murd sebelum melakukan kebugaran jasmani denyut nadi terhitung 96 dan tekanan darah 120/70, tetapi setelah melakukan tes kebugaran jasmani denyut nadi dan tekanan darahnya meningkat menjadi 162 dan 110/70.Nrl sebelum melakukan kebugaran jasmani denyut nadi terhitung 80 dan tekanan darah 110/70, tetapi setelah melakukan tes kebugaran jasmani denyut nadi dan tekanan darahnya meningkat menjadi 140 dan 110/60. Ruk sebelum melakukan kebugaran jasmani denyut nadi terhitung 60 dan tekanan darah 120/70, tetapi setelah melakukan tes kebugaran jasmani denyut nadi dan tekanan darahnya meningkat menjadi 160 dan 130/70. N H.S sebelum melakukan kebugaran jasmani denyut nadi terhitung 84 dan tekanan darah 120/80, tetapi setelah melakukan tes kebugaran jasmani denyut nadi dan tekanan darahnya meningkat menjadi 172 dan 120/70.

WS sebelum melakukan kebugaran jasmani denyut nadi terhitung 72 dan tekanan darah 120/80, tetapi setelah melakukan tes kebugaran jasmani denyut nadi dan tekanan darahnya meningkat menjadi 160 dan 130/70.Rti sebelum melakukan kebugaran jasmani denyut nadi terhitung 72 dan tekanan darah 100/60, tetapi setelah melakukan tes kebugaran jasmani denyut nadi dan tekanan darahnya meningkat menjadi 156 dan 90/160.I N sebelum melakukan kebugaran jasmani denyut nadi terhitung 76 dan tekanan darah 110/80, tetapi setelah melakukan tes kebugaran jasmani denyut nadi dan tekanan darahnya meningkat menjadi 100 dan 
90/70. IP sebelum melakukan kebugaran jasmani denyut nadi terhitung 74 dan tekanan darah 110/70, tetapi setelah melakukan tes kebugaran jasmani denyut nadi dan tekanan darahnya meningkat menjadi 100 dan 130/60.Ar sebelum melakukan kebugaran jasmani denyut nadi terhitung 72 dan tekanan darah 110/70, tetapi setelah melakukan tes kebugaran jasmani denyut nadi dan tekanan darahnya meningkat menjadi 106 dan 130/60. Aj sebelum melakukan kebugaran jasmani denyut nadi terhitung 100 dan tekanan darah 110/70, tetapi setelah melakukan tes kebugaran jasmani denyut nadi dan tekanan darahnya meningkat menjadi 160 dan 120/70. Yeni sebelum melakukan kebugaran jasmani denyut nadi terhitung 70 dan tekanan darah 120/60, tetapi setelah melakukan tes kebugaran jasmani denyut nadi dan tekanan darahnya meningkat menjadi 146 dan 90/60.

\section{KESIMPULAN}

Kebugaran merupakan kebutuhan pokok dalam melakukan aktivitas untuk kehidupan sehari-hari. Orang yang bugar berarti ia sehat secara dinamis. Sehat dinamis akan menunjang terhadap berbagai aktivitas fisik maupun psikis. Kebugaran yang dimiliki seseorang akan memberikan pengaruh yang positif terhadap kinerja seseorang dan juga akan memberikan dukungan yang positif terhadap produktivitas bekerja atau belajar. Terdapat beberapa tes untuk mengetahui tingkat kebugaran seseorang seperti Push Up, Sit Up, loncat, dan lari sprint. Beberapa tes tersebut dilakukan dengan pengukuran denyut nadi permenit sebelum dan sesudah sebagai salah satu indikator untuk menentukan kebugaran suatu individu. Masing-masing individu memiliki tingkat kebugaran yang berbeda-beda tergantung pola hidup, kebiasaan, dan faktor lain yang mempengaruhi kebugaran jasmani itu sendiri.

Indikator yang digunakan sebagai acuan tingkat kebugaran individu adalah tekanan darah sebelum dan setelah melakukan tes. Tekanan darah yang menurun atau tetap setelah melakukan tes mengindikasikan bahwa individu tersebut mempunyai tingkat kebugaran yang rendah. Sebaliknya jika saat melakukan aktivitas terjadi peningkatan tekanan darah lebih lama dan pembuluh darah lebih 
cepat kembali ke keadaan normal setelah melakukan aktivitas menandakan bahwa individu tersebut memiliki tingkat kebugaran yang tinggi.

\section{DAFTAR PUSTAKA}

Karhiwikarta W. 1991. Melengkapi Fasilitas Perusahaan Untuk Mempertemukan Kebutuhan Karyawan. Dalam Seminar Bisnis dalam Fitness Indonesia. Jakarta: PKO Menpora. 1-7.

Adisapoetra, dkk. 1999. Tes \& Latihan Kebugaran Jasmani untuk Anak Usia Sekolah. Jakarta: Kantor Menteri Negara Pemuda dan Olahraga.

Cooper, K H. 1983. The Aerobic Ways. New York: M Evans and Company, Inc: 30

Sugiyono. 2012. Metode Penelitian Kuantitatif Kualitatif dan R\&D. Bandung: Alfabeta.

Sugiyono. 2011. Metode Penelitian Kombinasi. Bandung: Alfabeta. 


\section{GAYA SELINGKUNG}

1. Jurnal Halaman Olahraga Nusantara menerbitkan karya ilmiah dan hasil penelitian dalam seluruh kajian ilmu keolahragaan, baik pendidikan, kepelatihan, dan lainya dalam pengembangan teori dan konsep yang belum pernah dipublikasikan. Jurnal ini memuat (1) kumpulan informasi baru, (2) hasil objektif dari suatu kajian ilmu keolahragaan, dan (3) rekomendasi.

2. Penulisan naskah menggunakan bahasa Indonesia secara benar. Panjang naskah antara 7-20 halaman, kertas ukuran quarto, diketik 1,5 spasi, tipe huruf Times New Roman, ukuran huruf 12, margin atas dan kiri 4 cm, kanan dan bawah $3 \mathrm{~cm}$.

3. Naskah ditulis dengan sistematika dan ketentuan sebagai berikut.

a. Judul: ditulis dengan singkat, padat, terdiri dari 5-15 kata, dan menggunakan bahasa Indonesia, harus mencerminkan substansi keilmuan yang diuraikan pada batang tubuh artikel. Judul utama (main title) dan anak judul (subtitle) dipisahkan dengan dua titik. Judul artikel dicetak 15 mm dibawah tepi atas, dengan huruf capital-kecil tebal. Judul subbab peringkat 1 dicetak capital semua, rata tepi kiri, tebal, peringkat 2 dicetak capital kecil, rata tepi kiri, tebal; peringkat 3 dicetak kapital-kecil, rata tepi kiri, miring-tebal.

b. Nama penulis: Nama penulis artikel ditulis tanpa disertai gelar akademik atau gelar apapun. Nama lengkap dengan gelar akademik boleh ditulis disebelah bawah halaman pertama artikel. Nama lembaga tempat bekerja penulis juga dibuat sebagai catatan kaki dihalaman pertama. Jika lebih dari tiga penulis, hanya penulis utama saja yang dicantumkan dibawah judul; nama penulis lain ditulis dalam catatan kaki.

c. Abstrak artikel kajian ilmiah/ konseptual adalah ringkasan dari isi artikel yang dituangkan secara padat menggunakan bahasa Indonesia dan bahasa inggris. Abstrak hasil penelitian memuat masalah atau tujuan, metode, dan hasil penelitian. Abstrak terdiri dari 100-300 kata yang disusun dalam satu 
paragraph dengan format esei bukan enumeratif, dan diketik dengan spasi tunggal serta dengan format yang lebih sempit dari teks utama.

d. Kata Kunci terdiri dari 3-5 kata, yaitu istilah-istilah yang mewakili ide atau konsep dasar yang dibahas dalam penulisan karya ilmiah. Kata kunci lazimnya berupa kata dasar atau kata yang berdiri sendiri (tunggal) bukan rangkaian kata.

e. Naskah hasil penulisan ditulis dengan urutan (1) judul, (2) nama penulis, (3) abstrak, (4) kata kunci, (5) bagian pendahuluan yang harus di akhiri dengan rumusan singkat (1-2 kalimat) tentang hal-hal pokok yang akan dibahas dan tujuan dari pembahasan. Untuk artikel hasil penelitian berisi (a) rumusan masalah, (b) tujuan, dan (c) deskripsi singkat mengenai kerangka pemikiran dalam pendahuluan, (6) isi memuat (a) metode penelitian, (b) hasil penelitian, dan (c) pembahasan. (8) simpulan dan saran, (9) daftar pustaka.

f. Naskah diluar hasil penelitian ditulis dengan urutan (1) judul, (2) nama penulis, (3) abstrak, (4) kata kunci, (5) pendahuluan yang memuat latar belakang dan rumusan masalah, (6) isi, (7) simpulan, dan (8) daftar pustaka.

g. Table dan gambar/ bagan di usahakan dicetak dalam satu halaman, nomor dan judul table dan gambar dicetak di atas table dengan huruf tebal. Isi dalam table dicetak dengan huruf normal (tidak tebal). Table hanya menggunakan garis horizontal (horizontal border)

h. Penulisan daftar pustaka

1) Buku ditulis dengan urutan: (a) nama akhir, (b) koma, (c) nama depan penulis, (d) titik, (e) tahun penerbitan, (f) titik, (g) judul buku dalam huruf miring, (h) titik, (i) edisi jika ada, (j) titik, (k) kota penerbitan, (l) titik dua, (m) nama penerbit, dan (n) titik.

2) Artikel ditulis dengan urutan: (a) nama akhir, (b) koma, (c) nama depan penulis, (d) titik, (e) tahun penerbitan, (f) titik, (g) tanda petik dua, (h) judul artikel, (i) titik, (j) tanda petik tutup, (k) nama jurnal dalam cetak miring, (l) volume, (m) nomor, dan (n) titik. Apabila artikel diterbitkan 
disuatu buku, tulis kata "dalam" sebelum nama editor buku tersebut, dan buku harus ditulis didalam daftar pustaka.

3) Skripsi, thesis, atau disertasi ditulis dengan urutan: (a) nama akhir, (b) koma, (c) nama depan penulis, (d) titik, (e) tahun, (f) titik, (g) judul dalam huruf miring, (h) skripsi/thesis/disertasi pada (nama perguruan tinggi yang bersangkutan), (i) nama kota, (j) titik dua, (k) tulisan "tidak diterbitkan", dan (1) titik. 